\title{
Amycolatopsis keratiniphila sp. nov., a novel keratinolytic soil actinomycete from Kuwait
}

\author{
Correspondence \\ Reiner M. Kroppenstedt \\ kdt@dsmz.de
}

\author{
Azza A. Al-Musallam, ${ }^{1}$ Sheikha S. Al-Zarban, ${ }^{1}$ Yunis A. Fasasi, ${ }^{1}$ \\ Reiner M. Kroppenstedt ${ }^{2}$ and Erko Stackebrandt ${ }^{2}$ \\ ${ }^{1}$ Kuwait University, Department of Biological Sciences, Microbiology Division, P.O. Box 5969,
13060 Safat, Kuwait \\ ${ }^{2}$ DSMZ - Deutsche Sammlung von Mikroorganismen und Zellkulturen, Mascheroder Weg $1 \mathrm{~b}$ \\ 38124 Braunschweig, Germany
}

\begin{abstract}
A keratinolytic, nocardioform actinomycete, strain $\mathrm{D} 2^{\top}$, was isolated from Kuwait marsh soil by the bait technique using animal wool. Strain $\mathrm{D} 2^{\top}$ was an aerobic, Gram-positive organism that produced light-grey aerial mycelium but no specific spore chains. 16S rDNA sequence analyses and chemotaxonomic markers were consistent with the classification of strain $D 2^{\top}$ in the genus Amycolatopsis, i.e. it had meso-diaminopimelic acid in its peptidoglycan, arabinose and galactose as its diagnostic sugars, the polar lipids phosphatidylinositol, phosphatidylethanolamine, hydroxyphosphatidylethanolamine and diphosphatidylglycerol, menaquinone $\mathrm{MK}-9\left(\mathrm{H}_{4}\right)$ and an iso-/anteiso-branched fatty acid pattern combined with 10-methyl-branched and 2-hydroxybranched fatty acids. Amycolatopsis japonica was the closest phylogenetic neighbour of strain $\mathrm{D}^{\top}{ }^{\top}$, showing 99.4\% $16 \mathrm{~S}$ rDNA sequence similarity with the novel strain. $A$. japonica and strain $\mathrm{D} 2{ }^{\top}$ could be clearly separated from each other on the basis of their low DNA-DNA reassociation value (55.9\%). These data, together with its distinct physiological traits, led to the conclusion that strain $\mathrm{D} 2^{\top}$ represented a novel species within the genus Amycolatopsis, for which the name Amycolatopsis keratiniphila (type strain $\mathrm{D} 2^{\top}=\mathrm{DSM} 44409^{\top}=\mathrm{NRRL} B 24117^{\top}$ ) is proposed.
\end{abstract}

The ability to degrade hair or other keratin-based substances, such as horn or feathers, is not widely distributed among bacteria. The degradation of natural keratin by Lysobacter spp. has been reported previously (Reichenbach, 1992). Martin \& So (1969) isolated a strain of myxobacteria that could use autoclaved feathers and wool as sole $\mathrm{C}$ and $\mathrm{N}$ sources, but it was unable to attack untreated material. Among the actinomycetes, members of the genera Cellulomonas (Goodfellow, 1971), Streptomyces (Jensen, 1930) and Pilimelia (Kane, 1966) show keratinolytic activities. Species of the genus Pilimelia are well known for their ability to degrade keratin, as they are frequently isolated from soil using the hair bait technique. Species of this genus are easily differentiated from all other actinomycetes by their typical sporangia, which release zoospores when the mycelium is flooded with water (Vobis et al., 1986). Until now, there have been no reports concerning keratindegrading Amycolatopsis spp. The aim of this study was to clarify the taxonomic position of a novel keratindegrading Amycolatopsis isolate, strain $\mathrm{D} 2^{\mathrm{T}}$, by morphological, physiological, chemotaxonomical and molecular biological methods.

The GenBank/EMBL accession number for the $16 \mathrm{~S}$ rDNA sequence of Amycolatopsis keratiniphila $\mathrm{D}^{\top}$ is AJ278496.
Strain $\mathrm{D} 2^{\mathrm{T}}$ was isolated from marsh soil in Kuwait that had been baited with sterilized and defatted wool; the strain was deposited with the DSMZ as Amycolatopsis keratiniphila DSM $44409^{\mathrm{T}}$. Determinations of morphological traits, colour of the aerial and substrate mycelia, and of soluble pigments were performed as described previously (Shirling \& Gottlieb, 1966). Biochemical tests were done as described by Lechevalier et al. (1986). Strain $\mathrm{D} 2^{\mathrm{T}}$ showed the typical macroscopic and microscopic appearance of a member of the genus Amycolatopsis (Henssen et al., 1987; Kothe et al., 1989; Embley, 1992; Holt et al., 1994), having dirty-white aerial mycelium which became light-grey in ageing cultures grown on GYM medium ( 4 g glucose $\mathrm{l}^{-1}, 4 \mathrm{~g}$ yeast extract $\mathrm{l}^{-1}, 10 \mathrm{~g}$ malt extract $\left.1^{-1}\right)$. No specific pigments were produced by the strain. In older cultures, aerial hyphae disintegrated into spore-like structures.

Cell material used for chemotaxonomic analyses was obtained in trypticase soy broth (BBL) after 4 days incubation of strain $\mathrm{D} 2{ }^{\mathrm{T}}$ at $28^{\circ} \mathrm{C}$ on a rotary shaker. The cell material was harvested by centrifugation and washed twice with distilled water. Analyses of amino acids and sugars were carried out using the methods of Staneck \& Roberts (1974). Menaquinones and polar lipids were extracted following the procedure of Minnikin et al. (1984). Polar lipids and menaquinones were analysed by 
TLC (Minnikin et al., 1977) and HPLC (Kroppenstedt, 1982, 1985), respectively. Analyses of fatty acids were performed following the methods of Miller (1982) and Sasser (1990). The presence of mycolic acids was checked by the method of Minnikin et al. (1975). Whole-cell hydrolysates of strain $\mathrm{D} 2^{\mathrm{T}}$ contained meso-diaminopimelic acid as the diamino acid of the peptidoglycan and galactose and arabinose as the major cell-wall sugars. Menaquinone with a tetrahydrogenated isoprenoid chain of nine isoprene units [MK-9 $\left.\left(\mathrm{H}_{4}\right)\right]$ was found as the dominant isoprenoid quinone. The polar lipid pattern was composed of phosphatidylinositol, phosphatidylethanolamine, hydroxyphosphatidylethanolamine and diphosphatidylglycerol. This pattern matched quite well with the patterns for other Amycolatopsis spp. reported by Lechevalier et al. (1986). The fatty acid pattern was composed mainly of iso-/anteiso-branched fatty acids. Of diagnostic value is the combination of 10-methyl-branched iso-branched fatty acids together with 2-hydroxy-branched fatty acids (fatty acid pattern $3 \mathrm{f}$ sensu Kroppenstedt \& Evtushenko, 2002), i.e. iso- $\mathrm{C}_{14: 0}(13.9 \%)$, iso- $\mathrm{C}_{15: 0}(8 \cdot 0 \%)$, iso- $\mathrm{C}_{16: 0}(33 \cdot 5 \%)$, iso- $\mathrm{C}_{17: 0}(0 \cdot 8 \%)$, anteiso- $\mathrm{C}_{15: 0}(1 \cdot 9 \%)$, anteiso- $\mathrm{C}_{17: 0}(1 \cdot 3 \%)$, 10-methyliso- $\mathrm{C}_{17: 0}(1 \cdot 0 \%), 2$-hydroxy-iso- $\mathrm{C}_{16: 0}(7 \cdot 4 \%), 2$-hydroxyanteiso- $\mathrm{C}_{15: 0}(0 \cdot 9 \%), \mathrm{C}_{15: 0}(7 \cdot 1 \%), \mathrm{C}_{16: 0}(2 \cdot 0 \%), \mathrm{C}_{16: 1}$ $(4 \cdot 9 \%), \mathrm{C}_{17: 0}(7 \cdot 6 \%)$ and $\mathrm{C}_{17: 1}(9 \cdot 9 \%)$. Mycolic acids were not detected. All chemotaxonomic properties of strain $\mathrm{D} 2^{\mathrm{T}}$ were consistent with its classification in the genus Amycolatopsis (Lechevalier et al., 1986; Henssen et al., 1987; Yassin et al., 1993).

Genomic DNA extraction, PCR-mediated amplification of the 16S rDNA and purification of PCR products were carried out as described previously (Rainey et al., 1996). The AE2 editor (Maidak et al., 1999) was used to align the almost-complete $16 \mathrm{~S}$ rDNA sequence of strain $\mathrm{D}^{\mathrm{T}}$ (1439 nt) against the 16S rDNA gene sequences of representatives of the main actinobacterial lineages and then against members of the genus Amycolatopsis. Phylogenetic analyses (De Soete, 1983; Felsenstein, 1993) followed described methods. The almost-complete $16 \mathrm{~S}$ rDNA sequence of strain $\mathrm{D} 2^{\mathrm{T}}$, consisting of $1439 \mathrm{nt}$, was compared to $16 \mathrm{~S}$ rDNA sequences of members of the class Actinobacteria. With intrageneric relationships ranging between $99 \cdot 4$ and $94 \cdot 3 \%$ sequence similarity, strain $\mathrm{D} 2^{\mathrm{T}}$ was most closely related to members of the genus Amycolatopsis, especially to Amycolatopsis japonica (99.4\% sequence similarity). A phylogenetic dendrogram (Fig. 1) was constructed from a distance matrix using the treeing algorithm of De Soete (1983). Distance-matrix and maximum-likelihood analyses gave consistent results, in that strain $\mathrm{D} 2{ }^{\mathrm{T}}$ clustered with the type strains of $A$. japonica, Amycolatopsis azurea and Amycolatopsis orientalis (Fig. 1).

Strain $\mathrm{D} 2^{\mathrm{T}}$ was able to utilize all of the tested carbon sources (Table 1) and could grow in the presence of $5 \%$ $\mathrm{NaCl}$. The strain grew at $10^{\circ} \mathrm{C}$ but not at $45^{\circ} \mathrm{C}$; the optimal growth temperature was between 25 and $28^{\circ} \mathrm{C}$. In addition, strain $\mathrm{D} 2^{\mathrm{T}}$ could grow on feathers as sole $\mathrm{C}$

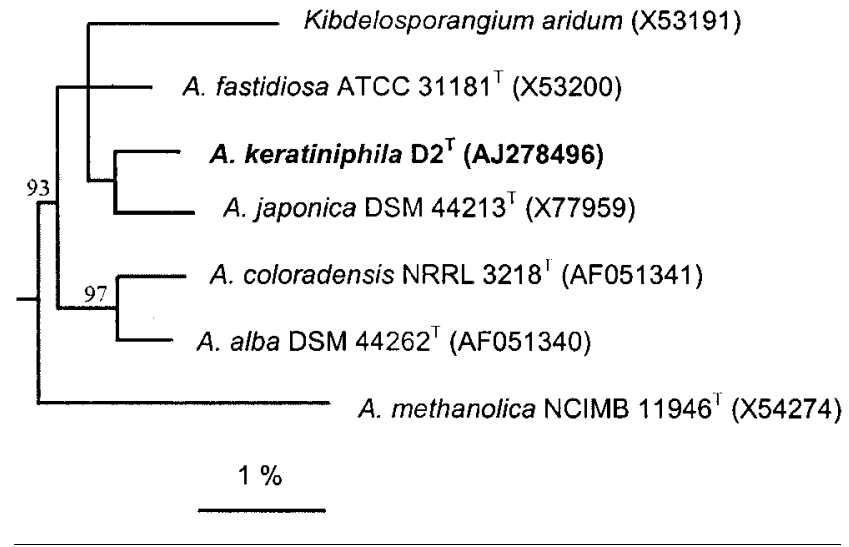

Fig. 1. Dendrogram (De Soete, 1983), based on 16S rDNA sequences, displaying the phylogenetic positions of strain $D 2^{\top}$ and related members of the genus Amycolatopsis. Numbers at the nodes are bootstrap values, expressed as a percentage of 1000 resamplings. Bar, sequence divergence. More distantly related members of the genus Amycolatopsis served as a root for the dendrogram (Kim et al., 2002). Strain numbers and 16S rDNA accession numbers (in parentheses) of reference organisms are given.

and $\mathrm{N}$ sources, and tolerated $25 \% \mathrm{NaCl}$ for growth. Based on these properties, strain $\mathrm{D} 2^{\mathrm{T}}$ could be distinguished from its closest phylogenetic relatives (Table 1).

DNA was isolated by chromatography on hydroxyapatite by the method of Cashion et al. (1977). DNA-DNA hybridization was carried out as described by De Ley et al. (1970), with the modifications described by Huss et al. (1983) and Escara \& Hutton (1980), using a Gilford System model 2600 spectrometer equipped with a Gilford model 2527-R thermoprogrammer and plotter. Renaturation rates were computed with the TRANSFER.BAS program (Jahnke, 1992). The DNA-DNA relatedness of strain D2 ${ }^{\mathrm{T}}$ to A. japonica was $59 \cdot 5 \%$, indicating that they were distinct species based on the criteria set forth by Wayne et al. (1987) for strains of the same species.

Based on phenotypic and genotypic data, we conclude that strain $\mathrm{D} 2^{\mathrm{T}}$ merits separate species status within the genus Amycolatopsis. We, therefore, propose the name Amycolatopsis keratiniphila for strain $\mathrm{D} 2^{\mathrm{T}}$, the sole strain of this species.

\section{Description of Amycolatopsis keratiniphila sp. nov.}

Amycolatopsis keratiniphila (ke.rat.i.ni' phi.la. N.L. n. keratinum keratin; Gr. adj. philos loving; N.L. adj. keratiniphila keratin-loving, referring to the ability of the species to degrade keratin).

Aerobic, Gram-positive, non-motile actinomycete, which forms light-grey aerial mycelium. No specific endo- or exopigments are produced. In ageing cultures, aerial and 
Table 1. Characteristics useful for distinguishing between species of the Amycolatopsis orientalis-Amycolatopsis mediterranei group

Strains: 1, Amycolatopsis keratiniphila $\mathrm{D} 2^{\mathrm{T}} ; 2$, Amycolatopsis alba $44262^{\mathrm{T}}$; 3, A. azurea DSM $43854^{\mathrm{T}} ; 4$, Amycolatopsis coloradensis DSM $44425^{\mathrm{T}} ; 5$, A. japonica DSM $44123^{\mathrm{T}} ; 6$, A. mediterranei DSM $43304^{\mathrm{T}} ; 7$, A. orientalis subsp. orientalis DSM $40040^{\mathrm{T}} ; 8$, A. orientalis subsp. lurida DSM $43134^{\mathrm{T}}$. Data from Lechevalier et al. (1986), Henssen et al. (1987), de Boer et al. (1990), Labeda (1995) and Chun et al. (1999). -, Negative or absent; +, positive or present; ND, no data; W, weak positive. None of the strains produced a yellowish-green or dirty-white to grey aerial mycelium. All strains were able to utilize $\mathrm{D}(+)$-cellobiose, D-fructose, mannitol and D-xylose.

\begin{tabular}{|c|c|c|c|c|c|c|c|c|}
\hline Characteristic & 1 & 2 & 3 & 4 & 5 & 6 & 7 & 8 \\
\hline \multicolumn{9}{|l|}{ Colour of aerial mycelium: } \\
\hline Blue & - & - & + & - & - & - & - & - \\
\hline Purple & - & - & + & - & - & - & - & \\
\hline White & - & + & - & - & + & + & + & + \\
\hline White to olive-buff & - & - & - & + & - & - & - & - \\
\hline Production of soluble pigment & - & - & + & + & - & - & - & - \\
\hline \multicolumn{9}{|l|}{$\begin{array}{l}\text { Growth on sole carbon source } \\
(1 \%, w / v) \text { : }\end{array}$} \\
\hline Adonitol & + & + & + & - & + & - & + & + \\
\hline $\mathrm{L}(+)$-Arabinose & + & + & + & - & + & + & + & + \\
\hline D-Galactose & + & + & - & + & + & - & + & ND \\
\hline Glycerol & + & + & + & $\mathrm{ND}$ & $\mathrm{ND}$ & + & + & + \\
\hline Inositol & + & + & + & + & + & + & + & W \\
\hline Lactose & + & + & + & - & + & + & + & + \\
\hline Melibiose & + & + & + & - & + & + & - & - \\
\hline Raffinose & + & + & + & - & + & + & + & - \\
\hline $\mathrm{L}(+)$-Rhamnose & + & - & - & - & - & - & + & - \\
\hline Sucrose & + & + & + & + & + & + & + & - \\
\hline \multicolumn{9}{|l|}{ Growth at: } \\
\hline $10^{\circ} \mathrm{C}$ & + & - & + & + & + & + & + & - \\
\hline $45^{\circ} \mathrm{C}$ & - & - & - & - & - & - & + & - \\
\hline $\begin{array}{l}\text { Growth in the presence of } \\
5 \%(\mathrm{w} / \mathrm{v}) \mathrm{NaCl}\end{array}$ & + & - & + & + & $\mathrm{W}$ & $\mathrm{W}$ & $\mathrm{W}$ & + \\
\hline
\end{tabular}

substrate mycelia disintegrate into spore-like structures. Optimal growth is obtained on GYM medium ( 4 g glucose $\mathrm{l}^{-1}, 4 \mathrm{~g}$ yeast extract $\mathrm{l}^{-1}, 10 \mathrm{~g}$ malt extract $\mathrm{l}^{-1}$ ) at $28^{\circ} \mathrm{C}$. Whole-cell hydrolysates contain meso-diaminopimelic acid, arabinose and galactose. The predominant menaquinone is MK-9 $\left(\mathrm{H}_{4}\right)$. The polar lipids are phosphatidylinositol, phosphatidylethanolamine, hydroxyphosphatidylethanolamine and diphosphatidylglycerol. Major fatty acids are iso$\mathrm{C}_{16: 0}(33 \cdot 5 \%)$, iso- $\mathrm{C}_{14: 0}(13 \cdot 9 \%), \mathrm{C}_{17: 1}(9 \cdot 9 \%)$, iso- $\mathrm{C}_{15: 0}$ $(8 \cdot 0 \%), \mathrm{C}_{17: 0}(7 \cdot 6 \%), 2$-hydroxy-iso- $\mathrm{C}_{16: 0}(7 \cdot 4 \%)$ and $\mathrm{C}_{15: 0}(7 \cdot 1 \%)$; minor fatty acids are $\mathrm{C}_{16: 1}(4 \cdot 9 \%), \mathrm{C}_{16: 0}$ $(2 \cdot 0 \%)$, anteiso- $\mathrm{C}_{15: 0}(1 \cdot 9 \%)$, anteiso- $\mathrm{C}_{17: 0}(1 \cdot 3 \%), 10$ methyl-iso- $\mathrm{C}_{17: 0}(1 \cdot 0 \%), 2$-hydroxy-anteiso- $\mathrm{C}_{15: 0}(0 \cdot 9 \%)$ and iso- $\mathrm{C}_{17: 0}(0 \cdot 8 \%)$. Mycolic acids are not synthesized. Other characteristics of the species can be found in Table 1 .

The type strain of Amycolatopsis keratiniphila is $\mathrm{D} 2^{\mathrm{T}}$ $\left(=\right.$ DSM $44409^{\mathrm{T}}=$ NRRL B24117 $\left.{ }^{\mathrm{T}}\right)$. Isolated from agricultural soil in Kuwait using animal wool as bait.

\section{Acknowledgements}

We thank Ina Kramer, Gabriele Pötter, Michaela Schmidt, Bettina Sträubler and Jolantha Swiderski for their technical assistance.

\section{References}

Cashion, P., Holder-Franklin, M. A., McCully, J. \& Franklin, M. (1977). A rapid method for the base ratio determination of bacterial DNA. Anal Biochem 81, 461-466.

Chun, J., Kim, S. B., Oh, Y. K. \& 7 other authors (1999). Amycolatopsis thermoflava sp. nov., a novel soil actinomycete from Hainan Island, China. Int J Syst Bacteriol 49, 1369-1373.

de Boer, L., Dijkhuizen, L., Grobben, G., Goodfellow, M., Stackebrandt, E., Parlett, J. H., Whitehead, D. \& Witt, D. (1990). Amycolatopsis methanolica sp. nov., a facultatively methylotrophic actinomycete. Int J Syst Bacteriol 40, 194-204.

De Ley, J., Cattoir, H. \& Reynaerts, A. (1970). The quantitative measurement of DNA hybridization from renaturation rates. Eur $J$ Biochem 12, 133-142.

DeSoete, G. (1983). A least squares algorithm for fitting additive trees to proximity data. Psychometrika 48, 621-626.

Embley, T. M. (1992). The family Pseudonocardiaceae. In The Prokaryotes, 2nd edn, pp. 1188-1213. Edited by A. Balows, H. G. Trüper, M. Dworkin, W. Harder \& K.-H. Schleifer. New York: Springer-Verlag.

Escara, J. F. \& Hutton, J. R. (1980). Thermal stability and renaturation of DNA in dimethyl sulfoxide solutions: acceleration of the renaturation rate. Biopolymers 19, 1315-1327.

Felsenstein, J. (1993). PHYLIP (phylogeny inference package), version 3.5c. Department of Genetics, University of Washington, Seattle, USA.

Goodfellow, M. (1971). Numerical taxonomy of some nocardioform bacteria. J Gen Microbiol 69, 33-80.

Henssen, A., Kothe, H. W. \& Kroppenstedt, R. M. (1987). Transfer of Pseudonocardia azurea and "Pseudonocardia fastidiosa" to the genus Amycolatopsis, with emended species description. Int J Syst Bacteriol 37, 292-295.

Holt, J. G., Krieg, N. R., Sneath, P. H. A., Stayley, J. T. \& Williams, S. T. (1994). Bergey's Manual of Determinative Bacteriology, 9th edn. Baltimore: Williams \& Wilkins.

Huss, V. A. R., Festl, H. \& Schleifer, K.-H. (1983). Studies on the spectrometric determination of DNA hybridization from renaturation rates. Syst Appl Microbiol 4, 184-192.

Jahnke, K.-D. (1992). Basic computer program for evaluation of spectroscopic DNA renaturation data from GILFORD System 2600 spectrometer on a PC/XT/AT type personal computer. J Microbiol Methods 15, 61-73.

Jensen, H. J. (1930). Decomposition of keratin by soil microorganisms. J Agric Sci 20, 390-398.

Kane, W. D. (1966). A new genus of Actinoplanaceae, Pilimelia, with a description of two species, Pilimelia terevasa and Pilimelia anulata. J Elisha Mitchell Sci Soc 82, 220-230.

Kim, B., Sahin, N., Tan, G. Y. A., Zakrzewska-Czerwinska, J. \& Goodfellow, M. (2002). Amycolatopsis eurytherma sp. nov., a thermophilic actinomycete isolated from soil. Int $J$ Syst Evol Microbiol 52, 889-894. 
Kothe, H. W., Vobis, G., Kroppenstedt, R. M. \& Henssen, A. (1989). A taxonomic study of mycolateless, wall chemotype IV actinomycetes. Syst Appl Microbiol 12, 61-69.

Kroppenstedt, R. M. (1982). Separation of bacterial menaquinones by HPLC using reverse phase (RP-18) and a silver-loaded ion exchanger. J Liq Chromatogr 5, 2359-2367.

Kroppenstedt, R. M. (1985). Fatty acid and menaquinone analysis of actinomycetes and related organisms. In Chemical Methods in Bacterial Systematics, no. 20 SAB Technical Series, pp. 173-199. Edited by M. Goodfellow \& D. E. Minnikin. London: Academic Press.

Kroppenstedt, R. M. \& Evtushenko, L. I. (2002). The family Nocardiopsaceae. In The Prokaryotes: an Evolving Electronic Resource for the Microbiological Community, 3rd edn (release 3.11). Edited by M. Dworkin. New York: Springer (http://et.springer-ny.com:8080/ prokPUB/index.htm).

Labeda, D. P. (1995). Amycolatopsis coloradensis sp. nov., the avoparcin (LL-AV290)-producing strain. Int J Syst Bacteriol 45, 124127.

Lechevalier, M. P., Prauser, H., Labeda, D. P. \& Ruan, J.-S. (1986). Two new genera of nocardioform actinomycetes: Amycolata gen. nov. and Amycolatopsis gen. nov. Int J Syst Bacteriol 36, 29-37.

Maidak, B., L., Cole, J. R., Parker, C. T., Jr \& 11 other authors (1999). A new version of the RDP (Ribosomal Database Project). Nucleic Acid Res 27, 171-173.

Martin, S. M. \& So, V. (1969). Solubilization of autoclaved feathers and wool by myxobacteria. Can J Microbiol 15, 1393-1397.

Miller, L. T. (1982). Single derivatization method for routine analysis of bacterial whole-cell fatty acid methyl esters, including hydroxy acids. J Clin Microbiol 16, 584-586.

Minnikin, D. E., Alshamaony, L. \& Goodfellow, M. (1975). Differentiation of Mycobacterium, Nocardia, and related taxa by thin-layer chromatographic analysis of whole-organism methanolysates. J Gen Microbiol 88, 200-204.
Minnikin, D. E., Patel, P. V., Alshamaony, L. \& Goodfellow, M. (1977). Polar lipid composition in the classification of Nocardia and related bacteria. Int J Syst Bacteriol 27, 104-117.

Minnikin, D. E., O’Donnell, A. G., Goodfellow, M., Alderson, G., Athaly, M., Schaal, K. P. \& Parlett, J. H. (1984). An integrated procedure for the extraction of isoprenoid quinones and polar lipids. J Microbiol Methods 2, 233-241.

Rainey, F. A., Ward-Rainey, N., Kroppenstedt, R. M. \& Stackebrandt, E. (1996). The genus Nocardiopsis represents a phylogenetically coherent taxon and a distinct actinomycete. lineage: proposal of Nocardiopsaceae fam. nov. Int J Syst Bacteriol 46, 1088-1092.

Reichenbach, H. (1992). The genus Lysobacter. In The Prokaryotes, 2nd edn, pp. 3256-3275. Edited by A. Balows, H. G. Trüper, M. Dworkin, W. Harder \& K.-H. Schleifer. New York: Springer-Verlag.

Sasser, M. (1990). Identification of bacteria by gas chromatography of cellular fatty acids. USFCC Newsl 20, 1-6.

Shirling, E. B. \& Gottlieb, D. (1966). Methods for characterization of Streptomyces species. Int J Syst Bacteriol 16, 313-340.

Staneck, J. L. \& Roberts, G. D. (1974). Simplified approach to identification of aerobic actinomycetes by thin-layer chromatography. Appl Microbiol 28, 226-231.

Vobis, G., Schäfer, D., Kothe, H.-W. \& Renner, B. (1986). Description of Pilimelia columellifera (ex Schäfer 1973) nom. rev. and Pilimelia columellifera subsp. pallida (ex Schäfer 1973) nom. rev. Syst Appl Microbiol 8, 67-74.

Wayne, L. G., Brenner, D. J., Colwell, R. R. \& 9 other authors (1987). International Committee on Systematic Bacteriology. Report of the ad hoc committee on reconciliation of approaches to bacterial systematics. Int J Syst Bacteriol 37, 463-464.

Yassin, A. F., Haggenei, B., Budzikiewicz, H. \& Schaal, K. P. (1993). Fatty acid and polar lipid composition of the genus Amycolatopsis: application of fast atom bombardment-mass spectrometry to structure analysis of underivatized phospholipids. Int J Syst Bacteriol 43, 414-420. 